\title{
Leveraging on Multidisciplinary Expertise for Landslide Disaster Risk Reduction and Management: A Case Study of a Limestone Hill Rockfall Hazard Assessment, Batu Caves, Selangor, Malaysia \\ (Memanfaatkan Kepakaran Berbilang Disiplin untuk Pengurangan dan Pengurusan Risiko Bencana Tanah Runtuh: Suatu Kajian Kes Penilaian Bahaya Runtuhan Batu Bukit Batu Kapur, Batu Caves, Selangor, Malaysia)
}

\section{Zainab Mohamed, Abd Ghani Rafek, Mingwei Zhang, Yanlong Chen, Goh Thian Lai*, Khamarrul AZAHARI \& ZAKARIA MOHAMAD}

\begin{abstract}
The United Nations Development Program agenda 2030 has charted out seventeen Sustainable Development Goals (SDG) whereby Malaysia as a member has strategically set the platform for growth. From the seventeen agendas, the SDG 9 (built resilient, promote inclusive and sustainable industrialization and foster innovation) and SDG 11 (make cities and human settlements inclusive, resilient, and sustainable) requires a paradigm shift from conventional engineering approach for environmentally induced disasters. Leveraging multidisciplinary ability and information and communications technology (ICT) in the landslide disaster studies had enabled regional-scale information acquirement for hazards identification, exposure, and risk assessment to meet the goals. The investigated limestone hill, Batu Caves is located within the suburban city of Kuala Lumpur. The land use around the hill is extensive and the area is highly populated with encroachment to the toe of the limestone hill. The purpose of the risk study was to assess the limestone hill's stability and hazards and the exposure that may lead to the vulnerability of the residences and commercial activities at and around the hill. Therefore, an engineering risk assessment study was carried out to determine rock fall hazard potential. The Terrestrial Laser Scanning survey was utilized to obtain the hillside's cross section. Discontinuity mapping was conducted to identify rock block size and rock slope was analyzed using rock mass classification system to determine rock slope quality. The rockfall analysis was conducted to identify rock rollout distance and produce rock fall hazard maps. The Slope Mass Rating for the slope BC1A, Parcel 1, Batu Caves was determined as 61, and is classified as a partially stable. The maximum rollout distance at this slope was $11 \mathrm{~m}$. This illustrates the practical output of this study that can be applied for mitigation and future development of the area.
\end{abstract}

Keywords: Disaster management; hazard assessment; rockfall

\section{ABSTRAK}

Agenda Program Pembangunan Pertubuhan Bangsa-Bangsa Bersatu 2030 telah memetakan tujuh belas Matlamat Pembangunan Lestari (SDG) dengan Malaysia sebagai ahli telah menetapkan pentas untuk pertumbuhan secara strategik. Daripada tujuh belas agenda, SDG 9 (membina daya tahanan, mempromosikan perindustrian inklusif dan lestari dan memupuk inovasi) dan SDG 11 (menjadikan bandar dan penempatan manusia inklusif, berdaya tahan dan lestari) memerlukan peralihan paradigma dalam pendekatan kejuruteraan konvensional untuk bencana yang disebabkan oleh alam sekitar. Untuk mencapai tujuan ini, keupayaan berbilang disiplin dan teknologi maklumat dan komunikasi (ICT) dalam kajian bencana tanah runtuh telah digunakan dalam pengumpulan maklumat skala serantau untuk pengenalpastian bahaya, pendedahan dan penilaian risiko. Bukit batu kapur yang dikaji, Batu Caves adalah terletak di pinggir bandar Kuala Lumpur. Penggunaan tanah di sekitar bukit batu kapur adalah meluas dan kawasan kaki bukit batu kapur diduduki dengan padat. Tujuan kajian risiko adalah untuk menilai kestabilan dan bahaya bukit batu kapur dan pendedahan keterancaman kepada kediaman dan kegiatan komersial di sekitar kawasan bukit. Oleh itu, satu kajian penilaian risiko 
kejuruteraan dilakukan untuk menentukan potensi bahaya jatuhan batuan. Survei Terestrial Imbasan Laser dijalankan untuk mendapatkan keratan rentas cerun bukit. Survei ketakselanjaran dilakukan untuk mengenal pasti saiz blok batuan dan cerun batuan dianalisis dengan menggunakan sistem pengelasan jasad batuan untuk menentukan kualiti cerun batuan. Analisis jatuhan batuan dilakukan untuk mengenal pasti jarak gulingan batuan dan menghasilkan peta bahaya jatuhan batuan. Perkadaran Jasad Cerun untuk cerun BC1A, Parcel 1, Batu Caves telah ditentukan sebagai 61 dan dikelaskan sebagai separuh stabil. Jarak maksima gulingan di cerun ini ialah $11 \mathrm{~m}$. Ini menunjukkan bahawa hasil praktikal kajian ini dapat digunapakai untuk mitigasi dan pembangunan kawasan pada masa hadapan.

Kata kunci: Jatuhan batuan; pengurusan bencana; penilaian bahaya

\section{INTRODUCTION}

The United Nations Development Program agenda 2030 has charted out seventeen Sustainable Development Goals (SDG) whereby Malaysia as a member has strategically set the platform for growth. From the seventeen agendas, the SDG 9 (built resilient, promote inclusive and sustainable industrialization and foster innovation) and SDG 11 (make cities and human settlements inclusive, resilient and sustainable) requires a paradigm shift from conventional engineering approach for environmentally induced disasters. Leveraging on multidisciplinary abilities and information and communications technology (ICT) in the landslide disaster studies had enabled regionalscale information acquisition for hazards identification, exposure and risk assessment to meet these goals. To uphold the sustainable geotechnical engineering practices for the environmentally induced hazards such as landslide hazards, Morgenstern (2000) has documented and recommended some good geotechnical engineering practices. The hazard and risk assessment method of recognizing the consequences needs to be conducted so that the effectiveness of mitigation against potential landslide disasters and their impacts can be prioritized to ensure safe and sustainable living.

An engineering risk assessment study of a limestone hill has significant influences on the urbanized geoenvironment adjacent to that limestone hill. Furthermore, the nature of the environmental influences on the hazard are themselves unique and intangible. The use of environmentally friendly LiDAR technology and a soft engineering approach can be an alternative method that provides a minimal impact, in addition to being a practical approach compared to the classical technique. The LiDAR technology is adopted to excerpt information of this limestone hill in Batu Caves, Selangor for a disaster risk reduction study. The investigated limestone hill is located within suburban city of Kuala Lumpur. The land use around the hill is extensive and the area is highly populated with encroachment to the toe of the limestone hill. Figure 1 shows the aerial view of the limestone hill. The purpose of the study was to assess the limestone hill's hazards and the exposure that may lead to the threat of the residences and commercial activities at and around the hill.

Rockfall has been identified as one of the common rock slope hazards generally initiated by existing geological conditions and enhanced by climate and biological events that warrant critical risk analysis within the context of environmental mechanisms. The mechanisms may include pore water pressure increases due to rainfall infiltration, erosion of surrounding material during heavy rainstorms, weathering of the rock, root growth and influenced by moving roots which are vibrated by high speed winds. Greater emphasis was given to the quantitative assessment of the rockfall hazard's uncertainty and variability in assessing the probability of the rockfall hazard and the consequences were evaluated from the LiDAR generated map. The information extracted enabled the modelling of the limestone hill's rockfall potential. Rockfall simulation was carried out and used as a predictive and verifying tool for the identification of hazards zoning. The hazardous zoning area was proposed for the safety and benefit of residential and the commercial activities affected by or benefiting from the development around the foot of the limestone hill.

Local researchers who focused on the Malaysian limestone rock slope stability assessment were Goh et al. (2018, 2017a, 2016,) and Mustapha et al. (2017). Ghani et al. (2015), Goh et al. (2017b), and Norbert et al. (2015) have conducted rock fall analysis on limestone hills at Batu Caves, Selangor and Lembah Kinta, Ipoh. Faruq et al. (2019) adopted terrestrial laser scanner (TLS) and photogrammetry technology for rock slope assessment. However, less studies have been conducted on the determination of hazardous zoning area for land used development planning using rock fall analysis. Therefore, in this study, integrated TLS technology and results of 
rock fall analysis-were adopted to determine hazardous zoning for land use development planning.

\section{TERRESTRIAL LASER SCANNING SURVEY}

Terrestrial Laser Scanning (TLS) is based on LiDAR (Light Detection and Ranging) technology and may also be called Terrestrial LiDAR. It is a ground-based remote sensing tool that is similar to Radar and Sonar but uses visible to near-infrared light emitted from a laser instrument that then records the reflected light waves from its targets. This method offers the advantages typical of noncontact techniques and moreover permits collection of short time dense 3D point clouds over the surface of interest, to record a perspective image (RGB data). It does not require deployment of reflectors, and results are obtained immediately. TLS is a geospatial tool with wide application for topographic mapping, detection of temporal and spatial geomorphic and tectonic changes such as earthquakes, volcanoes, landslides, stream morphology studies, glacier mass balance, snow depth measurements, biomass investigations in forestry and also for numerous engineering applications. The laser scanner is a static instrument that provides excellent coverage of objectives that range from several meters to over a kilometre in size. This is compared to airborne and satellite LiDAR systems that have resolutions of $10 \mathrm{~s}$ of centimetres to meters scales respectively. The long-range Terrestrial LiDAR namely RIEGL VZ 400 laser scanner was utilized in this study. The maximum measurement range for RIEGL VZ 400 is $1400 \mathrm{~m}$ with accuracy and precision of 8 and $5 \mathrm{~mm}$, respectively. This device has multi-target capability based on echo signal digitization and online waveform analysis enabling e.g. penetration of vegetation in multi and complex target situation. When fitted with a digital camera, the digital photographic images can be merged with point cloud data to produce photo-realistic 3D images.

\section{SITE GEOLOGY}

Batu Caves, Selangor is located $13 \mathrm{~km}$ to the north of Kuala Lumpur (Figure 1). Geologically the Klang Valley region is known for widespread occurrence of limestone formation (Figure 2). Under tropical humid conditions, the calcitic and dolomitic limestone or their metamorphosed equivalents develop tropical features which show spectacular tall steep-sided hills. Saim (1988) reported that Kuala Lumpur limestone has crystalline structure and is normally massive and interbedded with lenses of dolomite and marbles. It is fine to medium-grained. There is only one above surface exposure of this limestone as a hill which represents less than $1 \%$ of the total areal extent of this limestone bedrock. Extensive weathering and erosion by action of water has produced highly irregular bedrock with severe karstic features which is overlain by alluvium (Waltham \& Fookes 2003). These heterogeneous profiles and anomalies are major concern when dealing with this limestone hill. It was reported that Malaysia's climate together with the geological time of above ground exposure gives rise to karst type $\mathrm{kIV}$ (complex) or $\mathrm{kV}$ (extreme) (Waltham \& Fookes 2003) with possible cave width of 10 $\mathrm{m}$ or more. The rate of dissolution of limestone has been reported to be about $10-100 \mathrm{~mm} / 1000$ years (Waltham \& Fookes 2003). The geological hazards in limestone hills in addition to 'daylighting' geological discontinuities are caves, overhangs, stalactites, and stalagmites, where the overhanging stalactites may also pose risks of rockfall hazards (Minerals and Geoscience Department Malaysia 2013).

\section{MATERIALS AND METHODS}

A multidisciplinary study approach was adopted to evaluate the limestone hill and acquire information for hazards identification, exposure and hazard assessment. The arrangement of on-site limestone hill rock face exposure mapping has the drawback of accessibility. The scale and height of the hill makes it inaccessible to conduct a comprehensive geomechanics analysis. The TLS survey technique was used for on-site mapping of the limestone hill where the technology was adopted. The TLS produced the topographic limestone hill rock faces and important features related to geological structures of the hill for hazards parameter identification and hazard assessment. Although the TLS is able to compute the dip/orientation from the laser data, in particular the one above the eye-level however due to lack of expertise and skill to interpret the images has hindered further analysis process. Figure 3 shows the TLS workflow and data production processes.

The geomechanical survey of limestone hill rock mass conditions and discontinuities mapping were carried out and the strength of slope face rock was determined by Schmidt rebound hardness test. Based on the quality of the rock mass, the rockfall stability simulation study was carried out objectively. The quality of the rock slope face was analysed by the semi-quantitative method according to Rock Mass Rating (Bieniawski 1989), whereas the subsequent slope faces stability analysis was conducted according to the Slope Mass Rating method (Romana 1993). 


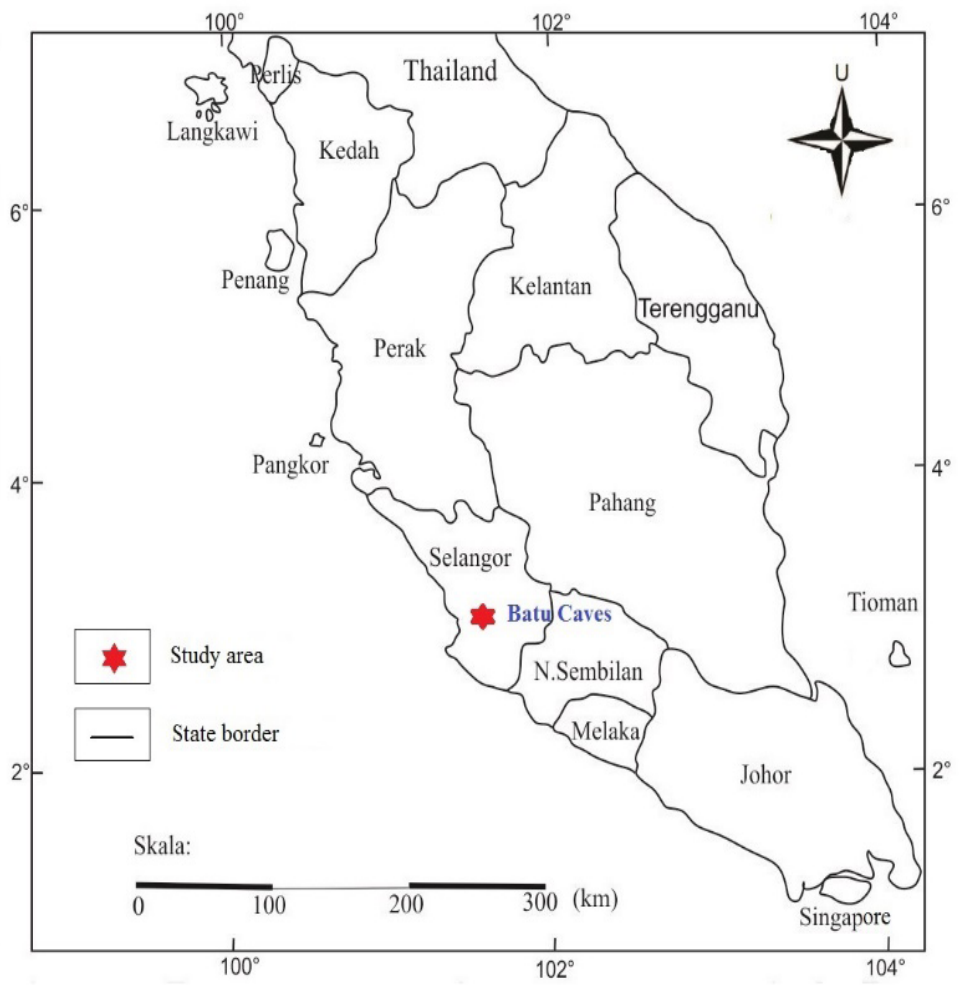

Map of Peninsular Malaysia

FIGURE 1. The location of study area in Peninsular Malaysia, Malaysia

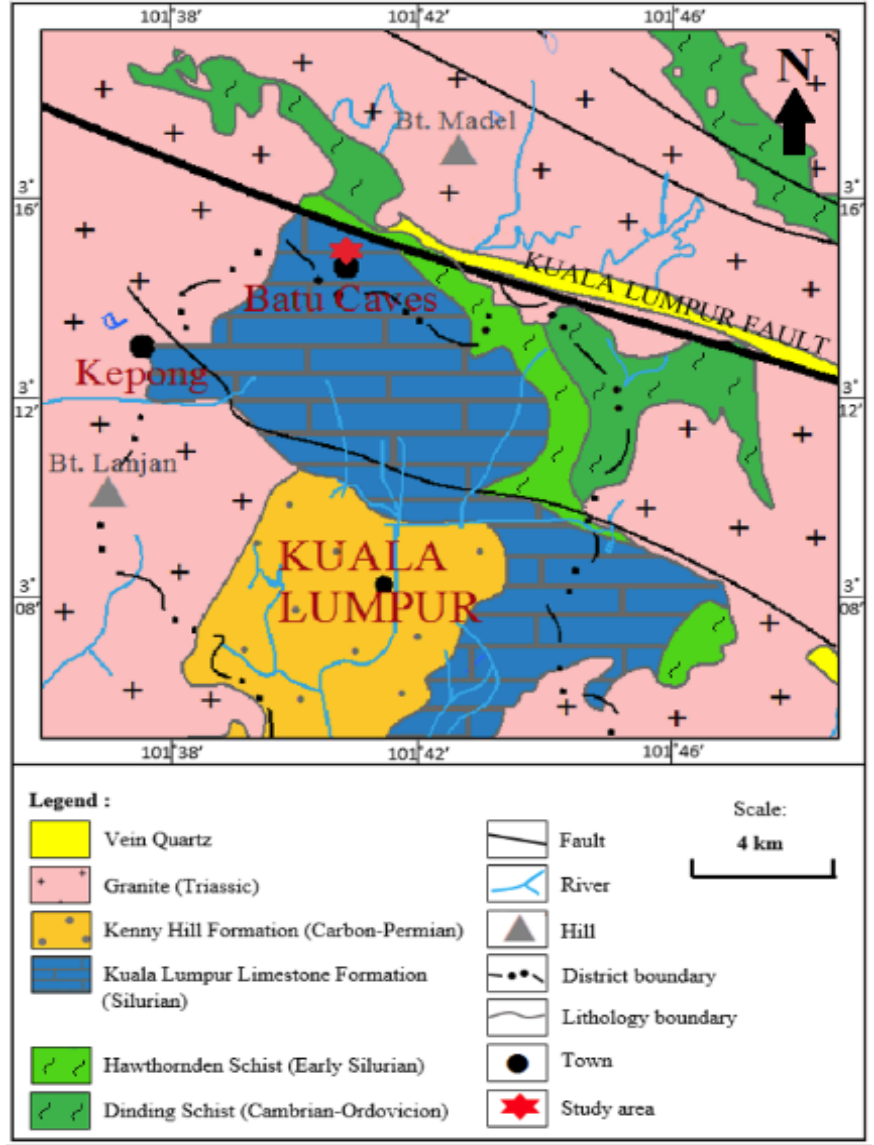

FIGURE 2. Geology map of study area

Source: Modified from Yunus Abd. Razak (2014) 


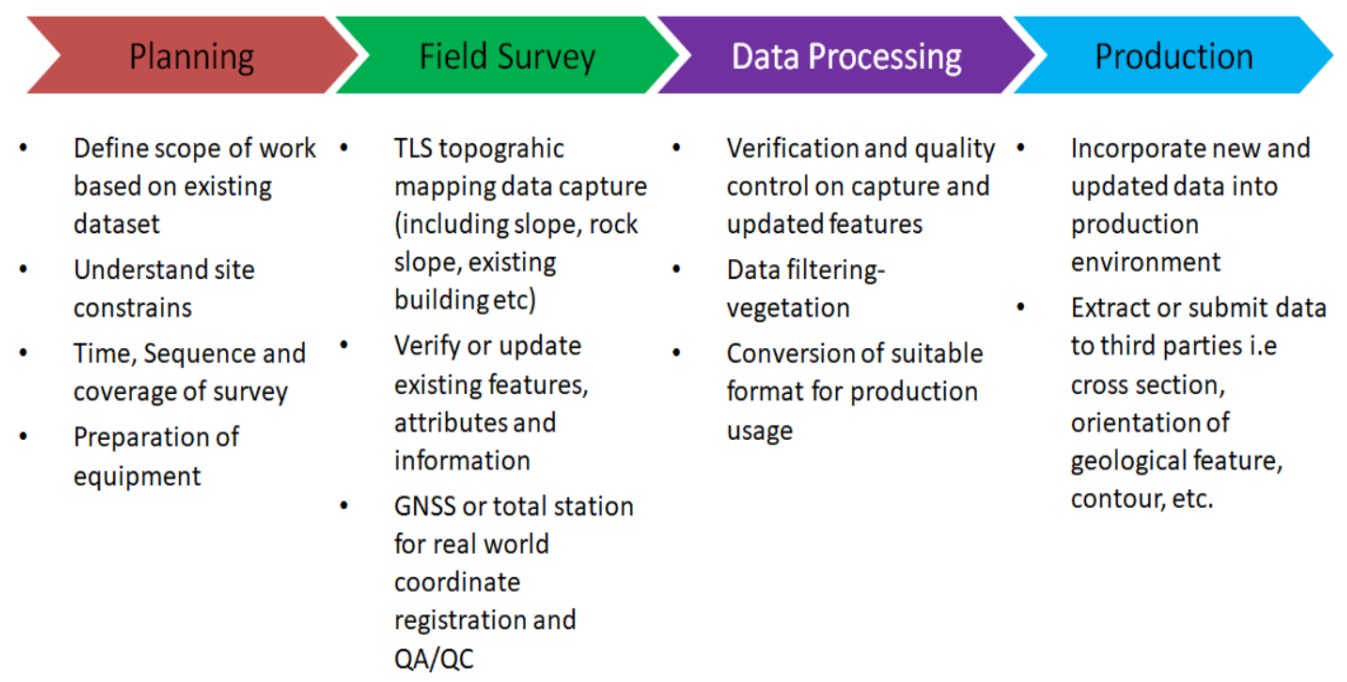

FIGURE 3. Terrestrial Laser Scanning (TLS) work flow and data production

\section{RESULTS AND DISCUSSION}

The whole study area was divided into three parts, namely Parcel 1, Parcel 2 and Parcel 3 where the coverage area of each is 24 acres, 110 acres, and 77 acres, respectively. The aerial photo of the limestone hill is as shown in Figure 4(a). Figure 4(b) shows the filtered image of the limestone hill without vegetation. Parcel 1 area is located within the religious temple, while Parcel 2 consists of $\mathrm{Kg}$. Sri Gombak Indah and Kg. Wira Damai. Taman Sunway Batu Caves is the location of Parcel 3. All of these infrastructures are densely populated at the foot and around the limestone hill. However, only the results of parcel 1 are discussed here. The slope at Parcel 1 was labeled as BC1A.

\section{LiDAR TOMOGRAPH}

Figure 5(a) shows the limestone hill rock face boundary derived from the LiDAR image. The slope face sectioning perpendicular to the face boundary was produced at an interval of $100 \mathrm{~m}$, resulting in a total of 98 sections. Figure 5(b) shows the shape of the limestone slope face cross-sections. Each cross-section was further analysed for rockfall probability assessment.

\section{GEOMECHANICAL ANALYSIS}

The random rebound hardness test on $\mathrm{BC} 1 \mathrm{~A}$ slope face concluded the surface hardness range from 10 to 30 with an equivalent uniaxial compressive strength of 15 to $90 \mathrm{MPa}$ (Deere \& Miller 1966). Hence the rock slope is classified as being composed of medium strong rock. Figure 6 shows an example of kinematic analysis for slope BC1A where Table 1 summarises the discontinuity parameters. The kinematic analysis estimates the potential mode of slope failure induced by the presence discontinuities and their orientation to slope face (Figure 6). The Rock Quality Designation (RQD) was determined by using the equation after Palmstrom (2005), hence the concluded RQD for slope $\mathrm{BC} 1 \mathrm{~A}$ is $86.9 \%$. The geomechanical rock mass rating after Bieniawski (1989) is shown in Table 2. The Slope Mass Rating, SMR (Ramona 1985) for the slope BC1A was determined as 61 , hence the slope is classified as a partially stable slope.

\section{ROCKFALL ANALYSIS}

The rockfall analysis for the rock slope sections was carried out using the Colorado Rockfall Simulation Program (CRSP). The software developed for the rockfall simulation is based on the equation of motion to estimate energy, speed and rock bouncing heights. The possible height of rockfall was assigned from the top, mid-height and toe of the slope, as shown in Figure 7(a), 7(b) and 7 (c). The rockfall was simulated based on the input parameters as shown in Table 3 . The summary of rockfall analysis is shown in Table 4. 

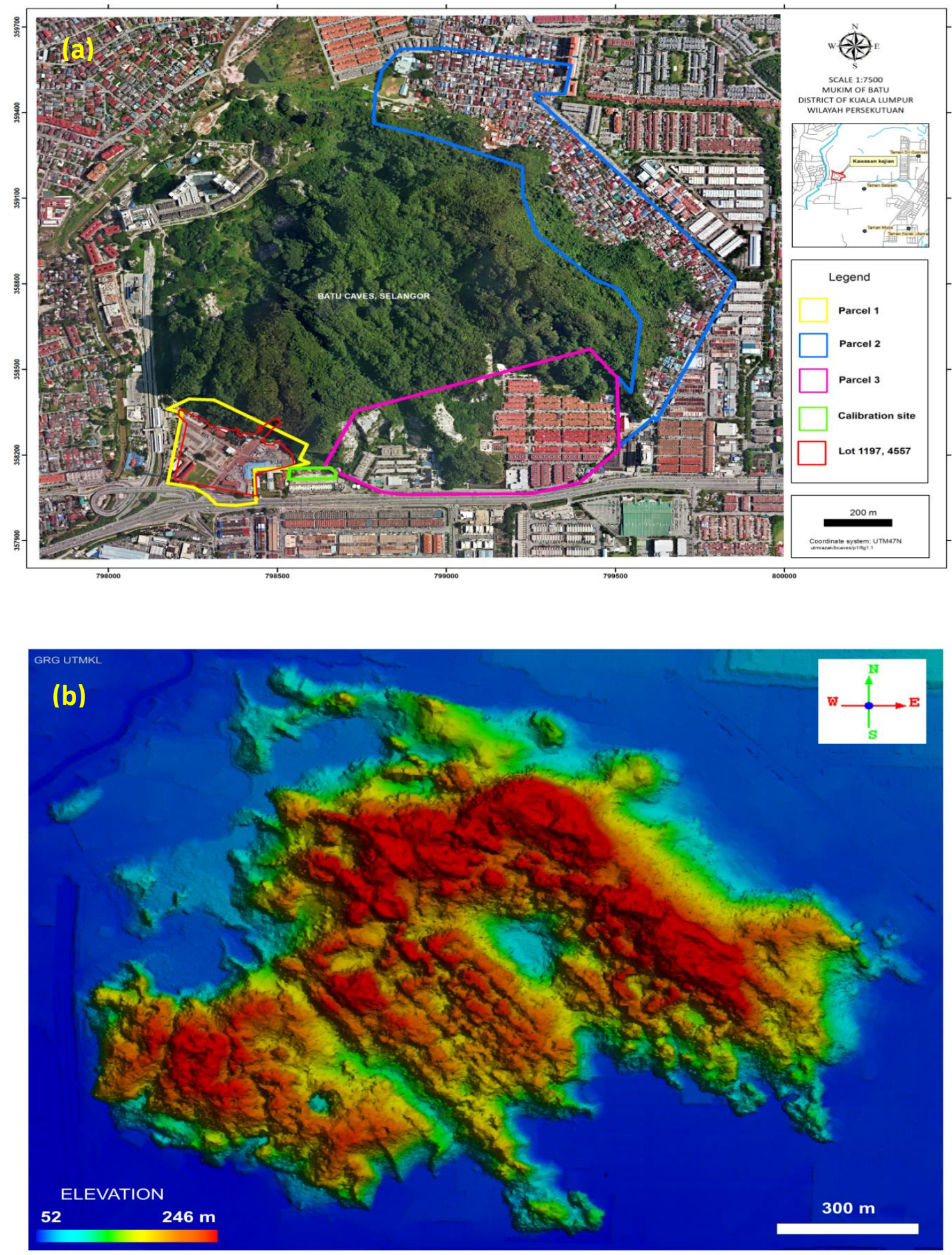

FIGURE 4. (a) Aerial view of limestone hill (b) TLS filtered image of limestone hill 

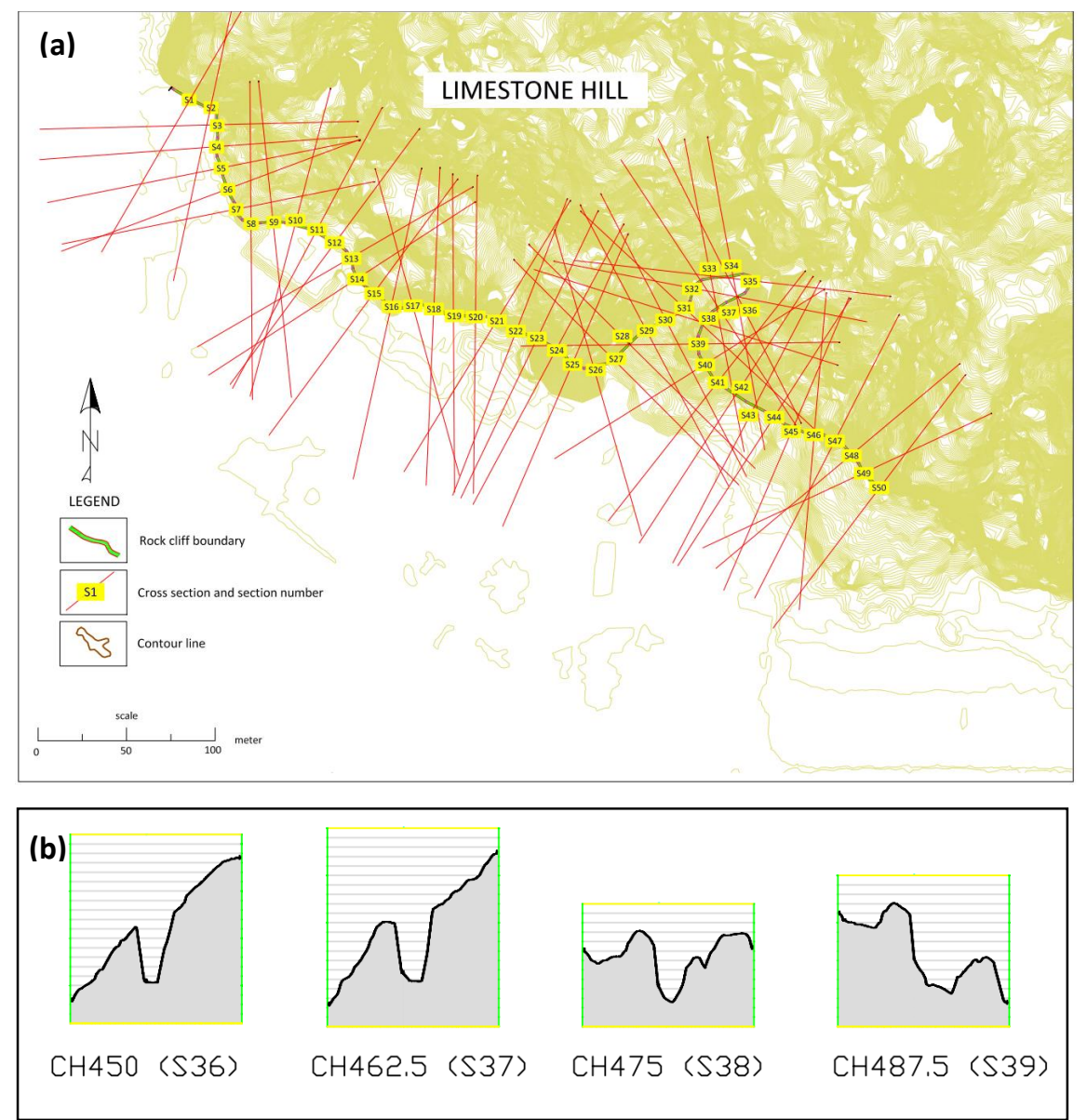

FIGURE 5. Limestone rock slope face cross section (a) Limestone rock slope face perimeter showing slope sectioning lines (b) Example of true slope cross sections derived from LiDAR image

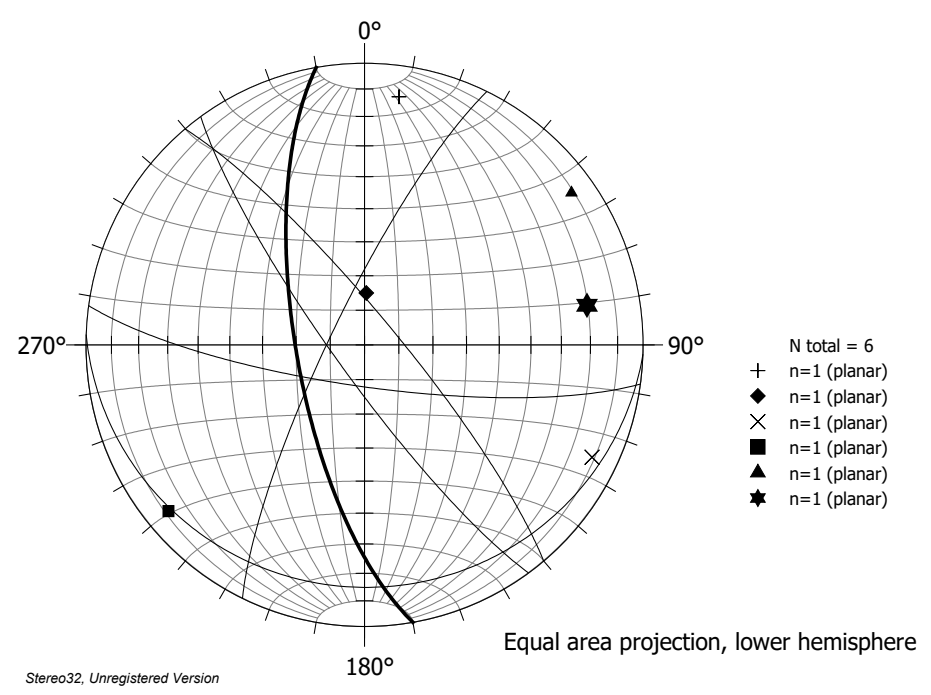

FIGURE 6. Kinematic analysis - Slope planar discontinuity BC1A 
TABLE 1. Slope BC1A discontinuity parameter

\begin{tabular}{ccccc}
\hline \multirow{2}{*}{ Joint } & \multicolumn{2}{c}{ Plane } & Joint spacing $(\mathrm{m})$ & Stereonet intensity (\%) \\
\cline { 2 - 3 } & Dip direction, $\alpha^{\circ}$ & Dip angle, $\beta^{\circ}$ & & \\
\hline J 1 & 188 & 78 & 0.050 & 43 \\
J 2 & 182 & 15 & 0.072 & 8 \\
J 3 & 296 & 80 & 1.070 & 5 \\
J 4 & 50 & 81 & 1.608 & 2 \\
J 5 & 234 & 81 & 2.782 & \\
Slope face & 260 & 70 & & \\
\hline
\end{tabular}

TABLE 2. RMR classification for slope BC1A

\begin{tabular}{|c|c|c|}
\hline Parameter & Value & Rating \\
\hline UCS (MPa) & $25-50$ & 4 \\
\hline RQD \% & $75-90$ & 17 \\
\hline Spacing(mm) & $\begin{array}{c}\mathrm{J} 1<60 \\
\mathrm{~J} 260-200 ; \\
\mathrm{J} 3 \& \mathrm{~J} 40.6-2.0 \mathrm{~m} ; \\
\mathrm{J} 5>2.0 \mathrm{~m}\end{array}$ & 8 \\
\hline Joint conditions & $\begin{array}{l}\text { Slightly rough surface, tight opening, no infill material, slightly } \\
\text { weathered }\end{array}$ & 20 \\
\hline Water & $>95 \%$ dry & 15 \\
\hline $\mathrm{RMR}_{\text {basic }}$ & Rock mass class II, good rock & 64 \\
\hline
\end{tabular}

The rollout distance as marked in red, yellow and green colours is to designate the high, intermediate and low-risk zoning (Figure 8(a)) based on suggestion of Minerals and Geoscience Department Malaysia (2013). The distance of the high hazard zone is the maximum rolling distance from CRSP simulation. The intermediate hazard zone distance from the toe was determined by subtracting the critical height of slope from the maximum rolling distance of rockfall (red zone). The distance of low hazard zone (green zone) is equal to the height of the critical slope marked from the boundary of the moderate zone. 

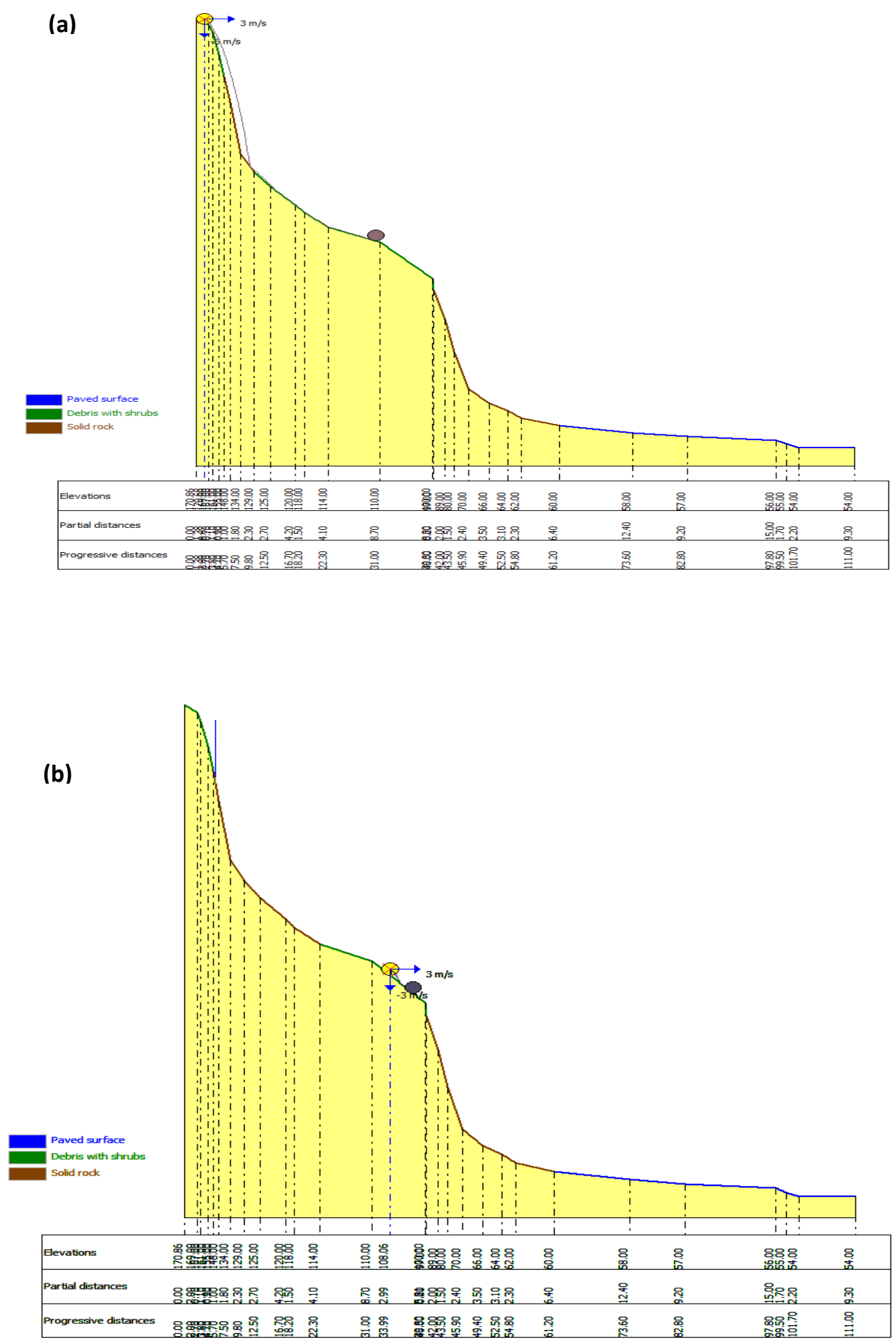


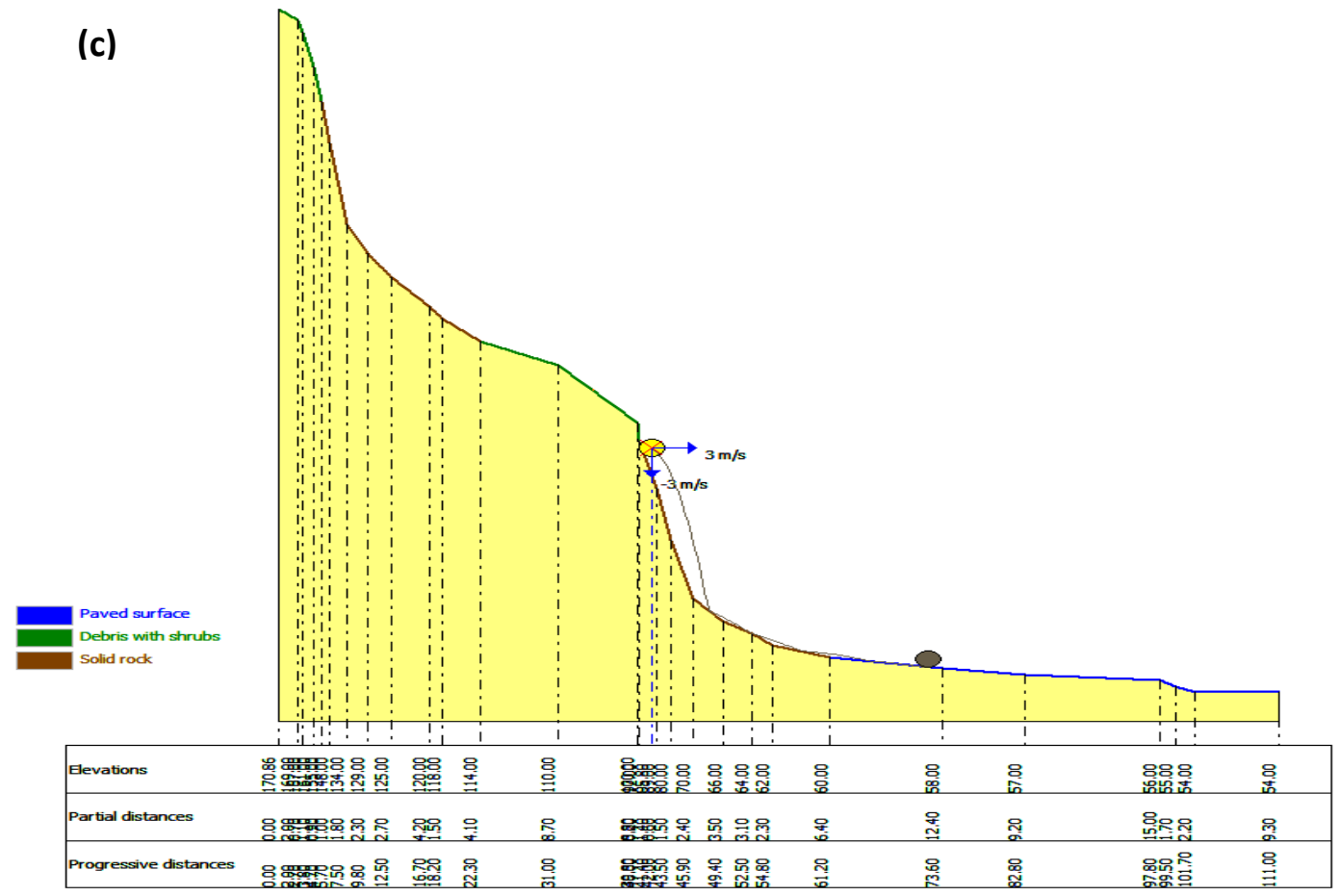

FIGURE 7. The setting of rock fall from the (a) top, (b) mid-height and (c) toe of slope

TABLE 3. Input data for rock fall simulation

\begin{tabular}{lc}
\hline Description & Value \\
\hline Rock density & $26 \mathrm{kN} / \mathrm{m}^{3}$ \\
Elastic modulus & $5 \mathrm{GPa}$ \\
X-axis velocity & $3 \mathrm{~m} / \mathrm{s}$ \\
Y-axis velocity & $-3 \mathrm{~m} / \mathrm{s}$ \\
Terminal velocity & $0.01 \mathrm{~m} / \mathrm{s}$ \\
\hline
\end{tabular}

TABLE 4. Summary of rock fall probability analysis for slope BC1A

\begin{tabular}{|c|c|c|}
\hline Block size(m) & Start of rock fall & Max. roll out (m) \\
\hline $1 \times 0.1$ & crest & -30.8 \\
\hline $1 \times 0.1$ & mid height & -23.4 \\
\hline $1 \times 0.1$ & toe & 11.1 \\
\hline $3 \times 2.8$ & crest & -30.9 \\
\hline $3 \times 2.8$ & mid height & -23.4 \\
\hline $3 \times 2.8$ & toe & 11.1 \\
\hline
\end{tabular}



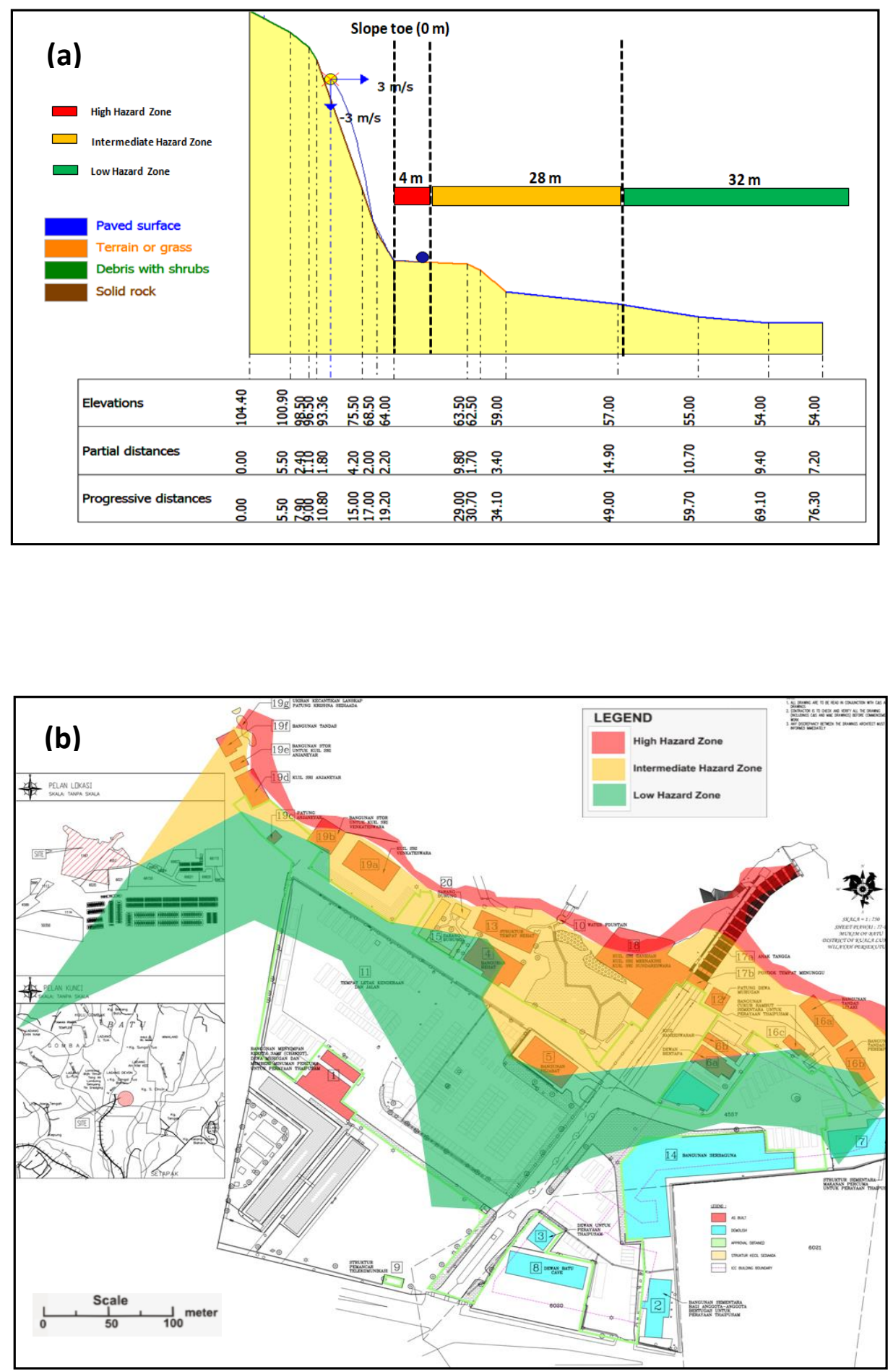

FIGURE 8. (a) Rollout distance zoning (b) the slope boundary and hazardous zoning area onto land use plan 


\section{ENGINEERING RISK ANALYSIS}

The trend of these results and with engineering judgement gives a reasonable and practical assessment of the hazards due to rockfall from the limestone hill adjacent to the populated area of interest. The information concluded from the analysis has successfully provided qualitative information on the probability of rockfall hazards concerning the stability of the limestone hill. Hence, the rockfall hazard map was superimposed onto the limestone hill development plan and a hazardous zone map of the infrastructures was produced to demarcate the area with different level of threat. The concern on the safety of the densely populated infrastructures around the hill was recognized. This is addressed by summarizing the engineering risk and consequence-to-life rating so that the specific property that falls within the hazardous zone was critically identified as shown in Figure 8(b). This means that the infrastructures in the high hazard zone (red zone) are exposed to very high rock fall threat. The intermediate hazard zone becomes a buffer zone of falling rock with moderate rock fall threat. The low hazard zone is safe and free of rock fall threat.

The TLS data was used to evaluate the limestone hill geomorphic processes and activities has value-added the ability to map, monitor and model the topographic terrain signature and geological features leading to an assessment of the stability of the limestone rock mass and its potential hazards. The threat of the element-at-risk subjected to limestone rockfall is the main causal factor of hazard. The presence of rock blocks from the previous rockfalls was obvious at the site. With the $240 \mathrm{~m}$ high limestone hill and the site constraints it is not accessible for conventional techniques for engineering risk assessment hence the use of LiDAR technology has made the study successful. The huge scale of the limestone hill found at the densely populated area is not possibly able to completely prevent rockfall, however, some mitigation measures have been recommended. The immediate measure recommended to the client was to carry out routine slope assessment by a qualified professional officer. There should also be a limit on further development or any human activities that may trigger instability from overhanging stalactites. The possible measures to reduce rockfall hazards are such as putting wire mesh draped over the rock face, remove loose rock blocks and wedges, provide berms and catch fences or barrier fences as effective means of catching rockfalls as these have a bouncing energy absorption capacity.

\section{CONCLUSION}

This scientific multidisciplinary study was implemented by the government agency, involving a team member comprising of geotechnical engineers, geoscientists and geospatial surveyors with knowledge and experience. The study unveiled that TLS can be a very important data source and mapping tool to evaluate regional scale hazard assessment in any complex environment. The increased prevalence of modern TLS systems and advanced point cloud processing had led the way to hazard mapping, risk assessment subsequently disaster risk management. The resulting hazard zonation map provides practical decision making tools for mitigation and future development of the investigated area. The results of this study also suit the objectives of SDG 9 and SDG 11 where the government and community are able to develop the area near limestone hills sustainably within zones free from rock fall threat.

\section{ACKNOWLEDGEMENTS}

This research was supported by Fundamental Research Grant Scheme FRGS/1/2020/WAB07/UKM/02/2. This research was also financially supported by the Selangor state agency. All parties and agencies co-operation to the success of this study is very much appreciated. This publication also was supported by Open Fund Project (SKLGDUEK2012) of State Key Laboratory for Geomechanics \& Deep Underground Engineering of China University of Mining and Technology/ China University of Mining and Technology (Beijing).

\section{REFERENCES}

Bieniawski, Z. 1989. Rock Mass Rating System. http://www. rockmass.net/short_on_RMR-system.pdf. Accessed on 30 August 2019.

Deere, D.U. \& Miller, R.P. 1966. Engineering Classification and Index Properties of Rock. Tech. Report Air Force Weapons Lab., New Mexico. pp. 65-116.

Faruq, M.S.M.A., Rasid Jaapar, A., Dali, M.F.M., Afiq, F.A.R., Jasmee, M.F., Harun, M.A., Hellmy, M.A.A., Abdullah, R.A. \& Goh, T.L. 2019. Advantages and limitations of Terrestrial Laser Scanner (TLS) and photogrammetry technology for rock slope assessment in Malaysian tropical terrains. In 12th Asian Regional Conference of IAEG. IEAG. p. 164.

Goh, T.L., Serasa, A.S., Rafek, A.G., Simon, N. \& Mohamed, T.M. 2017a. Rock fall run out analysis: Batu Caves, Selangor, Malaysia. Journal of Nepal Geological Society 54: 39. 
Goh, T.L., Razib, A.M.M., Mazlan, N.A., Rafek, A.G., Serasa, A.S., Simon, N., Surip, N., Ern, L.K. \& Mohamed, T.M. 2017b. Rock slope stability assessment of limestone hills, Southern Kinta Valley, Ipoh, Perak, Malaysia. Geological Behavior 1(2): 5-9.

Goh, T.L., Wong, J.M., Rafek, A.G., Serasa, A.S., Mazlan, N.A., Razib, A.M.M., Hussin, A., Lee, K.E. \& Mohamed, T.R. 2018. Stability assessment of limestone cave: Batu Caves, Selangor, Malaysia. Sains Malaysiana 47(1): 59-66.

Goh, T.L., Razib, A.M.M., Mazlan, N.A., Rafek, A.G., Serasa, A.S. \& Mohamed, T.M. 2016. Rock slope stability assessment using slope mass rating (SMR) method: Gunung Lang Ipoh Malaysia. Scholars Journal of Engineering and Technology (SJET) 4(4): 185-192.

Ghani, M.F.A., Simon, N., Goh, T.L. \& Rafek, A.G. 2015. A preliminary stability assessment using lineament density technique on cultural hotspots in limestone hills, Kinta Valley, Malaysia. In Proceedings of Regional Geoheritage Conference 2015. p. 79.

Minerals and Geoscience Department Malaysia. 2013. Guideline for Determination of Hazard Zone at Limestone Area. JMG.GP.15.

Morgenstern, N.R. 2000. Common Ground. In ISRM International Symposium. ISRM. pp. 1-30.

Mustapha, J.R.B., Sum, C.W. \& Rafek, A.G. 2017. Slope stability assessment of Kek Look Tong limestone hills, Kinta Valley, Perak, Malaysia. In 30th National Geoscience Conference \& Exhibition. Warta Geologi 43(3): 255.

Palmstrom, A. 2005. Measurements of and correlations between block size and rock quality designation. Tunnelling and Underground Space Technology 20(4): 362-377.

Romana, M. 1993. A geomechanical classification for slopes: Slope mass rating. In Comprehensive Rock Engineering: Rock Testing and Site Characterization, Vol 3, edited by Hudson, J.A. Michigan: Elsevier Science \& Technology Books. pp. 575-600.

Saim, S. 1988. Engineering Geological Mapping of Wilayah Persekutuan and Surrounding Areas. Volume 1: AmpangUlu Klang and Damansara Zones. Geological Survey of Malaysia. Urban Geology Section. Report No.UG/1/1988.

Simon, N., Ghani, M.F.A., Hussin, A., Goh, T.L., Rafek, A.G., Surip, N., Monam, T.R.T. \& Ern, L.K. 2015. Assessment of rockfall potential of limestone hills in the Kinta Valley. Journal of Sustainability Science and Management 10(2): 24-34.

Waltham, A.C. \& Fookes, P.G. 2003. Engineering classification of karst ground conditions. Quarterly Journal of Engineering Geology and Hydrogeology 36(2): 101-108.
Yunus Abd. Razak. 2014. Geological Map of Peninsular Malaysia. 9th ed. Kuala Lumpur: Mineral and Geoscience Malaysia.

Zainab Mohamed

Faculty of Civil Engineering

Universiti Teknologi MARA

40450 Shah Alam, Selangor Darul Ehsan

Malaysia

Abd Ghani Rafek

Engineering Geology Advisory

$11, \mathrm{SS} 21 / 12$

Damansara Utama

47400 Petaling Jaya, Selangor Darul Ehsan Malaysia

Mingwei Zhang, Yanlong Chen \& Goh Thian Lai

State key Laboratory for Geomechanics \&

Deep Underground Engineering

China University of Mining and Technology

Xuzhou 221116

People's Republic of China

Goh Thian Lai*

Department of Earth Sciences and Environment

Faculty of Science and Technology

Universiti Kebangsaan Malaysia

43600 UKM Bangi, Selangor Darul Ehsan

Malaysia

Khamarrul Azahari

UTM Razak School of Engineering and Advanced Technology

Universiti Teknologi Malaysia

Jalan Semarak

54100 Kuala Lumpur, Federal Territory

Malaysia

Zakaria Mohamad

Geomapping Technology Sdn Bhd.

Bangi Business Park

43650 Bandar Baru Bangi, Selangor Darul Ehsan Malaysia

*Corresponding author; email: gdsbgoh@gmail.com

Received: 4 June 2020

Accepted: 29 December 2020 